\title{
Silajın Aerobik Stabilitesini Etkileyen Faktörler ve İyileştirme Stratejileri
}

\author{
Hayrettin ÇAYIROĞLU*, İsa COŞKUN, Ahmet ŞAHIN \\ Ahi Evran Üniversitesi, Ziraat Fakültesi Zootekni Bölümü, Kırşehir \\ *e-posta: hayrettincayiroglu@ahievran.edu.tr \\ Geliş Tarihi/Received:08.04.2016 Kabul Tarihi/Accepted:01.06.2016
}

Öz: Aerobik stabilite, açılan bir silajın 1sınmadan ve bozulmadan kaldığı sürenin uzunluğu olarak tanımlanmaktadır. Silaj içine fermantasyon döneminde daha az olmakla birlikte, özellikle yemleme döneminde yoğun bir oksijen girişi meydana gelmektedir. Bu durum silajın bozulmasına neden olan maya, küf ve aerobik mikroorganizmaların aktif hale gelmesine ve sonuçta stabilitenin düşmesine sebep olmaktadır. Bunun bir sonucu olarak da silajda sıcaklık artışı, $\mathrm{pH}$ 'da yükselme ve kuru madde kaybı meydana gelmektedir. Silajların aerobik stabilitesini etkileyen faktörleri dört başlık altında toplamak mümkündür: (1) Silajlık materyalin fiziksel, kimyasal ve mikrobiyolojik özellikleri, (2) silajlı materyalin doldurulması ve silaj yoğunluğu, (3) silaj katkı maddeleri ve fermantasyon, (4) silajın hayvanlara yedirilmesindeki uygulamalar. $\mathrm{Bu}$ makalede silajların aerobik stabilitesini etkileyen faktörler ile stabiliteyi iyileştirme stratejileri tartışılmıştır.

Anahtar Kelimeler: Silaj, aerobik stabilite, istenmeyen mikroorganizmalar

\section{Factors Affecting the Aerobic Stability of Silage and Improvement Strategies}

\begin{abstract}
Aerobic stability (silage life), and from the pop-up remains intact as a silage warming is defined as the length of time. Although oxygen input into silage is insignificant at fermentation stage or during fermentation this entrence is excessives during feeding. This case causes activation of yeast, mould, and aerobic microorganisms which leads to deterioration of silage. Consequently silage temperature and $\mathrm{pH}$ increases with lost of dry matter. As a result of these, increase in temperature, rise in $\mathrm{pH}$, and loss of dry matter in silage occurs. Factors affecting the aerobic stability of silage can be grouped under four headings: (1) Physical, chemical and microbiological properties of silage material, (2) filling of silage material and silage density, (3) silage additives and fermentation, (4) feeding management. In this review factors affecting the aerobic stability of silage, and strategies for improving it were discussed.
\end{abstract}

Keywords: Silage, aerobic stability, unwanted microorganisms

\section{GíRiş}

Hayvan beslemede silajla ilgili karșılaşılan en önemli sorunlardan birisi aerobik stabilite sorunudur. Aerobik stabilite, açılan bir silajın hava ile temas ettikten sonra, ısınmadan ve bozulmadan kaldığı sürenin uzunluğu olarak tanımlanmaktadır (Kung, 2010; Toruk ve ark., 2010). Silo içerisine gerek fermantasyon gerekse de stabil dönemde hiç oksijen girmese bile silajın yemleme döneminde kullanılmak üzere açılmasıyla birlikte yoğun bir şekilde oksijen girişi olmaktadır. Bu durum silaj içerisinde silajın bozulmasına neden olan başta maya ve küf olmak üzere aerobik mikroorganizmaların aktif hale gelmesine neden olmaktadır. Bunun sonucu olarak da silajda sicaklık artışı, $\mathrm{pH}$ 'da yükselme ve kuru madde kaybı meydana gelmektedir (Muck ve Shinners, 2001; Danner ve ark., 2003; Filya ve ark., 2004; Kung, 2010; Wilkinson ve Davies, 2012).

Silaj içerisinde anaerobik mikroorganizmalardan olan Lactobacillus brevis veya Lactobacillus buchneri gibi laktik asit bakterilerinin etkin olması istenirken, Clostridia, Enterobactericiae, Bacilli ve Listeria gibi bakteriler, Candida, Hansenula, Pichia, Issatchenkia ve Saccharomyces türü mayalar, Aspergillus, Fusarium ve Pencillium türü küf mantarları istenmemektedir. Bu tür bakteri, maya ve küflerin gelişimi silajın $\mathrm{pH}$ 'sını arttırarak silaj kalitesinin düşmesine ve dolayısıyla da stabilitenin azalmasına neden olmaktadırlar (Muck ve Shinners, 2001; Basmacıoğlu ve Ergül, 2002; Danner ve ark., 2003; Kung, 2010). Özellikle yemleme döneminde söz konusu mikroorganizmalar 
ortamdaki şeker, laktik asit ve asetik asit gibi fermantasyon ürünlerini tüketerek büyük miktarlarda besin madde kaybına neden olur. Bunun sonucunda silo içerisinde karbondioksit ve su açığa çıkarak sıcaklık artar. Bu da silajın bozulmasına neden olur. $\mathrm{Bu}$ şekilde bozulmuş silajlarla yemlenen hayvanların yem tüketimi olumsuz yönde etkilendiğinden verimleri düşer. Ayrıca bozulmuş silajlarda oluşan küfler, hayvanların sağlığını tehdit ederek ölümcül olabilecek mikotoksinler üretebilmektedir. Söz konusu mikotoksinler hayvansal ürünler ile birlikte insanlara da geçerek sağlık açısından risk oluşturabilmektedirler (Liu ve ark., 2013).

\section{Aerobik Stabiliteye Etki Eden Faktörler}

Silajlarda aerobik bozulmanın en önemli göstergelerinden birisi maya, ikincisi ise küftür. Mayalar düşük oksijen sevilerinde bile yaşayabilme yeteneğine sahiptir. Buna ilaveten silajın aerobik bozulmasını sağlayan mikroorganizmaların büyüme ve gelişmesini etkileyen asıl faktörler, oksijen konsantrasyonu, sicaklık, su aktivitesi, pH, organik asit konsantrasyonu ve katkı maddelerinin kullanımıdır (Ashbell ve ark., 2002; Knicky, 2005). Silajın kalitesi ve stabilitesi açısından bu ana faktörleri etkileyen tüm özellikler silajın aerobik stabilitesini de etkilemektedir. Tüm silajlarda özellikle kullanım aşamasında aerobik bozulma kaçınılmazdır. Ancak, yemleme yönetimi bakımından değerlendirildiğinde asıl önemli olan konu, aerobik bozulma sonucundaki kayıpların minimize edilmesidir. Silaj materyalinin aerobik bozulmaya karşı direncini arttıracak uygulamalar, silajın açılması ve yedirilmesi esnasında kullanılan teknikler, silaj materyalinin aerobik bozulmaya karşı direncini arttırabilecek uygulamaların başında yer almaktadır (Koç ve ark., 2010).

Silajların aerobik stabilitesini etkileyen faktörleri şu ana başlıklar altında toplamak mümkündür: (1) Silajlık materyalin fiziksel, kimyasal ve mikrobiyolojik özellikleri, (2) silajlk materyalin doldurulması ve silaj yoğunluğu, (3) silaj katkı maddeleri ve fermantasyon ve (4) yemleme dönemindeki uygulamalar.

\section{Silajlık materyalinin fiziksel, kimyasal ve mikrobiyolojik özellikleri}

Kaliteli bir silaj yapabilmek için silolanacak yemlerin belirli fiziksel, kimyasal ve mikrobiyolojik özelliklere sahip olması gerekmektedir. Silolanacak materyal fiziki olarak içi dolu saplardan oluşmalı ve uygun büyüklüklerde parçalanmalıdır. Silajın iyice sıkıştııılması suretiyle içerisinde hava kalması önlenmektedir (Kutlu, 2015). Kimyasal yapı bakımından silolanacak yemlerin su ve karbonhidrat içeriklerinin silolamaya uygun olması gerekmektedir. Bu anlamda silajlı materyalin suda çözünebilir karbonhidrat (SÇK) içeriği ne kadar yüksek ise fermantasyon süresince meydana gelebilecek kuru madde kaybı da o oranda azalır ve kaliteli silaj elde edilir (Basmacıŏlu ve Ergül, 2002; Mohd-Setapar ve ark., 2012). Bitkilerin erken dönemde hasat edilmesi kuru madde içeriği düşük olan materyal elde edilmesine neden olacağından daha uzun süre soldurulması gerekmektedir. $\mathrm{Bu}$ durum ise materyalin besin maddeleri kaybının artmasına sebep olmaktadır. Bunun aksine materyalin geç dönemde hasat edilmesi ise kuru madde içeriğinin yükselmesine, SÇK içeriğinin azalmasına ve buna karşın lignin içeriğinin artmasına neden olmaktadır (Basmacioğlu ve Ergül, 2002).

Silolanan materyalin kuru madde içeriği aerobik stabiliteyi etkileyen önemli bir faktördür. Nitekim kuru madde içeriği düşük olan materyal ile yapılan silajların aerobik stabilitelerinin düştüğü bildirilmektedir (Filya ve ark., 2000). Basmacıŏglu ve Ergül (2002), nitelikli bir silaj için silolanacak materyalin kuru madde içeriklerinin \%25-35, MohdSetapar ve ark. (2012) ise \%25-40 arasında olması gerektiğini bildirmişlerdir.

Silolanacak bitki hasat edildiğinde, yapısında farklı türlerden oluşan doğal bir mikroflora vardır. $\mathrm{Bu}$ mikroflorada bulunan mikroorganizmaların türü ve sayısı fermantasyonun seyrini etkilemektedir (Kaya, 2005). Silajların aerobik stabilitesini en üst düzeye çıkarmak için silolanacak materyalin hasatı sırasında özellikle maya ve küf ile bulaşma riskinin en aza indirilmesi gerekmektedir. Bunun için alınabilecek önlemlerden birisi, eğer soldurma yapılacaksa materyalin hızlı bir şekilde soldurulmasıdır. Örneğin Wilkinson ve Davies (2012), çayır otu ve baklagil otlarının mekanik işlemlerle hızlı bir şekilde soldurulmasının, maya ve küf gelişini nispeten düşürdüğünü, buna karşın, hasat öncesi periyotta yüksek sıcaklık, nemli hava ve ürünün olgunluk derecesinin artması, özellikle Aspergillus türü küflerle bulaşma riskini arttırdığını bildirmişlerdir. Araştırıcılar ayrıca silajlık bitkiler içerisindeki çürümüş veya kokuşmuş kalıntı varlığı, rüzgâr, aşırı yağmur ve bitkinin geç 
biçilmesi veya hasat edilmesi gibi durumlar, silajlarda maya ve küf gelişimi riskini ISSN:1307-3311 arttırdığını da bildirmişlerdir.

\section{Silajlık materyalin doldurulması ve silaj yoğunluğu}

Kaliteli bir silaj yapmanın belli başlı kurallarını sıralayacak olursak; bunlardan birincisi silaj içerisine hava girişini hızlı bir şekilde engellemek, ikincisi hızlı bir laktik asit üretimi sağlayarak silaj pH'sını düşürmek, üçüncüsü ise fermantasyon sırasında silaj kütlesi içine hava girişini engellemektir (Kung, 2010; Liu ve ark., 2013). Silo dolumunun yavaş yapılması, materyalin iri parçalanması ve kötü sıkıştırma nedeniyle oluşan fazla hava, bitkinin uzun bir süre daha solunum yapmasına neden olur. Bu durum, bir yandan şeker ve proteinlerinin aşırı parçalanmasına sebep olurken diğer yandan silaj içerisinde istenmeyen mikroorganizmaların gelişmesini teşvik eder (Kung, 2010). Silonun doldurulması iki günü geçmemelidir. Bu sürenin uzaması silajda görülen kayıpların çok fazla artmasına neden olmaktadır. Dolum işleminden sonra, silo uygun bir malzeme ile mümkün olduğu kadar hızlı bir şekilde kapatılmalı ve içerideki havanın dışarı atılabilmesi için iyice sıkıştırılmalıdır (Filya, 2001; Kung, 2010).

Silaj yoğunluğu, bir $\mathrm{m}^{3}$ silaj kuru maddesinin $\mathrm{kg}$ olarak ağırlığı olup silaj1 yapilacak bitkinin çeşidine, ürün özelliklerine (parçalama uzunluğu, nem içeriği, dane oranı vs.) sıkıştırma süresine ve materyalin sıkıştırılmasını sağlayan ekipmanların (traktör, araba, vs.) ağırlığına ve lastik boyutuna göre değişim göstermektedir (Muck ve Holmes, 2000). Silajlarda yüksek yoğunluk iki nedenden dolayı tercih edilmektedir. Birincisi, yüksek yoğunluk, ürün içerisinde oluşabilecek muhtemel hava boşlukları ve gözenekleri azaltarak, doldurma, depolama ve yemleme esnasında silaj kütlesi içerisine oksijen girişini azaltmaktadır. İkincisi ise silo kapasitesinin artmasını sağlamaktır (Muck ve Holmes, 2000; D'Amours ve Savoie, 2005). Muck ve Holmes (2000), yonca silajinda kuru madde yoğunluğunu $106-434 \mathrm{~kg} / \mathrm{m}^{3}$, mısır silajının ise $125-378 \mathrm{~kg} / \mathrm{m}^{3}$ arasında olduğunu bildirmişlerdir. Johnson ve ark. (2002) ise mısır silajında, silo içerisine giren oksijen miktarını en aza indirmek için silaj yoğunluğunun minimum $225 \mathrm{~kg} / \mathrm{m}^{3}$ olması gerektiğini bildirmişlerdir.

Silaj içerisine giren oksijen miktarı, silaj yoğunluğu ve gözenek içerip içermemesi ile yakından ilişsilidir. Silajlarda yetersiz sıkıştırmanın bir sonucu olarak azalan silaj yoğunluğu ve silaj içerisinde oluşabilecek gözenekler geçirgenliğin artmasına sebep olmakta ve dolayısıyla da silaj açıldıktan sonra kütle içine doğru çok daha hızlı bir hava girişine neden olmaktadır. Bu durum silonun açılması ile birlikte, açılan yüzeyden kütle içine giren hava miktarının artmasına neden olmakta ve aerobik stabiliteyi olumsuz yönde etkilemektedir (Wilkinson ve Davies, 2013).

\section{Silaj katkı maddeleri, fermantasyon ve çevre sıcaklığı}

Silaj fermantasyonunda kullanılmak üzere çok sayıda kimyasal ve biyolojik katkı maddesi geliştirilmiş̧tir. Özellikle biyolojik kökenli katkı maddeleri, kullanımlarının oldukça kolay olması, güvenilir oluşları, toksik etkilerinin olmayışı, çevre kirliliği oluşturmamaları ve en önemlisi de doğal ürünler olmaları nedeniyle kimyasal kökenli katkı maddelerine göre daha fazla tercih edilmektedirler (Filya, 2002). Nitekim yapılan çeşitli araştırmalarda özellikle formik asit ve formik asit temeline dayalı koruyucular, katıldıkları silajların pH'larını çok kısa bir sürede düşürerek istenmeyen mikroorganizmaların (Clostridia, Enterobactericiae, Bacilli ve Listeria gibi bakteri, Candida, Hansenula, Pichia, Issatchenkia ve Saccharomyces türü mayalar ve Aspergillus, Fusarium, ve Pencillium türü mantarlar) gelişimini ve çoğalmasını önleyerek aerobik stabiliteyi iyileştirdikleri belirlenmiştir (Muck ve Shinners, 2001; Filya ve ark., 2004; Sucu ve Filya, 2006; Koç ve ark., 2010). Kaliteli silajlarda pH 3.8-4.8 arasında (Kaya, 2005) değişmekte olup, bozulmaya neden olan Enterobacteria grubu mikroorganizmalar pH'nın 6-7 olduğu ortamlarda etkili olurken, 5'in altındaki pH değerlerinde etkilerini kaybederler (Filya, 2001).

Silajların fermantasyon etkinliğini arttırmak için kullanılan en önemli katkı maddesi bakteriyel inokülantlardır. Bunlar genellikle Lactobacillus, Pediococcus ve Enterococcus cinsi mikroorganizmalardır. Ancak bakteriyal inokülantların büyük bir çoğunluğu, homofermentatif özellikteki laktik asit bakterilerini içermektedir. Bu tür mikroorganizmalar şekerleri ağılıklı olarak laktik aside fermente ederek pH'ı hızla düşürmekte ve bu sayede 
fermantasyonu iyileştirmektedir (Driehuis ve ark., 2001; Muck ve Shinners, 2001; Filya, IsSN:1307-3311 2002; Sucu ve Filya, 2006; Keleş ve Yazgan, 2011).

Bununla birlikte laktik asit bakteri inokülantlarının silajların aerobik stabiliteleri üzerindeki etkileri konusunda çelişkili sonuçların elde edildiği de ileri sürülmektedir. Muck ve Shinners (2001) ve Muck (2004), laktik asit bakteri inokülantlarının, aerobik stabilite açısından çok da etkin olmadığını, zira bunların ortamdaki doğal laktik asit bakterileri ile rekabete girerek onları baskı altına aldığını ileri sürmüşlerdir. Buna ilaveten silajlarda katkı maddesi olarak laktik asit bakterileri ile birlikte selülaz, hemiselülaz ve pektinaz gibi hücre duvarını parçalayan enzimler ile amilaz gibi nişastayı parçalayan enzimler kullanıldığında, laktik asit bakteri için ilave sübstrat açığa çıkararak silaj fermantasyonunu geliştirdiği, ancak aerobik stabiliteyi düşürdüğü belirtilmektedir (Polat ve ark., 2005). Nitekim Polat ve ark. (2005), silaj katkı maddesi olarak laktik asit bakterileri ve laktik asit bakteri+enzim karışımı inokülantların, mısır silajlarının fermantasyon, aerobik stabilite, hücre duvarı kapsamı ve toklularda ham besin maddelerinin sindirilme dereceleri üzerindeki etkilerini incelemek amacıyla yaptıkları çalışmada, her iki inokülantın, mısır silajının fermantasyon özelliklerini arttırırken aerobik stabiliteyi düşürdüğünü bildirmişlerdir. Benzer șekilde, Koç ve ark. (2008), bakteri+enzim (Lactobacillus plantarum ve Pediococcus acidilactici, ve amilaz enzimi) karışımı ilavesinin, mısır silajının fermentasyon özellikleri ve aerobik stabilitesi üzerine etkilerini inceledikleri çalışmada, bakteri+enzim karışımı ilavesinin fermantasyon özelliklerini iyileştirdiğini, ancak aerobik stabiliteyi düşürdüğünü bildirmişlerdir.

Aerobik stabilite, silaja ilave edilen inokülantın çeşidinden de etkilenmektedir. Heterofermantatif özellikteki silaj katkı maddesi olarak en yaygın kullanılanı laktik asit bakterisi $L$. buchneri'dir. Nitekim Keleş ve Yazgan (2011), balyalanmıș mısır silajlarına $L$. plantarum, E. Faecium'dan oluşan homofermentatif laktik asit bakterisi ve L. Buchneri'den oluşan heterofermentatif laktik asit bakterisi ilavesinin balyalanmış silajların fermantasyon özelliklerini etkilemediğini ancak L. buchneri ilavesinin aerobik stabiliteyi iyileştirdiğini bildirmişlerdir.

Silajların aerobik stabilitesini etkileyen faktörlerden birisi de fermantasyon sürecidir. Silo içerisinde anaerobik koşullar oluştuğunda silolanan materyalde bazı değişiklikler olmaya başlar. Öncelikle materyalin suyu serbest hale geçer. Bunun sonucu açığa çıkan enzimler bitki bünyesindeki polisakkaritleri parçalayarak laktik asit bakterileri için gerekli olan şekerleri üretirler. Silo içerisinde silo yeminin bozulmadan kalması laktik asit bakterileri tarafindan üretilen laktik asit sayesinde gerçekleştirilir (Filya, 2001; Mohd-Setapar ve ark., 2012). Laktik asit bakterileri aynı zamanda antibiyotik etkili maddeler meydana getirerek silo içerisinde çoğalması arzu edilmeyen asetik asit ve bütirik asit bakterilerinin gelişmesini engelleyerek yemin bozularak çürümesini önlemektedir (Basmacığlu ve Ergül, 2002).

Silaj fermantasyonunun başarısı çevre sıcaklı̆̆ı ile de yakından ilişkilidir (Mohd-Setapar ve ark., 2012). Artan çevre sıcaklığı, silajlarda özellikle Clostridia ve Enterobakteria gibi istenmeyen mikroorganizmaların gelişmesini teşvik ettiğinden silaj üretimine ek bir zorluk teşkil etmektedir. İyi doğranmamış ve yeterince sıkıştırılmamış mısır silajı, çevre sicaklığını $30^{\circ} \mathrm{C}$ olması durumunda yoğun bir aerobik bozulmaya maruz kalabilmektedir (Ashbell ve ark., 2002; Filya ve ark., 2004). Bu nedenle, sicak iklime sahip yerlerde aerobik bozulmayı önlemek için özel önlem alınması gerektiği belirtilmektedir (Ashbell ve ark., 2002). Sicaklık, silo içerisindeki laktik asit bakterileri gibi mikrobiyolojik katkı maddelerinin performansını da etkilemektedir. Nitekim Mohd-Setapar ve ark. (2012) $40^{\circ} \mathrm{C}$ 'nin üzerindeki sıcaklıklarda laktik asit bakterisi ilave edilse bile silaj kalitesinin düştügünü bildirmişlerdir. Koç ve ark. (2010), farklı ortam sıcaklıklarında $\left(20^{\circ} \mathrm{C}, 30^{\circ} \mathrm{C}\right.$ ve $37^{\circ} \mathrm{C}$ ), bileşiminde $\% 60$ formik asit, $\% 20$ sodyum formiyat ve $\% 20$ su içeren organik asit kullanımının etkilerini araştırdıkları çalışmalarında, fiğ-tahıl silajlarına organik asit ilavesinin yüksek sıcaklıklarda küf gelişimini kısmen azalttığını bildirmişlerdir.

\section{Silajın hayvanlara yedirilmesindeki uygulamalar}

Yemleme dönemi, silajın hayvanların beslenmesinde kullanılmak üzere silodan alınmaya başlandığı dönemdir. Silajın silodan alınmaya başlandığı andan itibaren silo içine sınırsız bir şekilde hava girişi olmakta ve silodaki anaerobik koşullar aerobik hale dönüşmektedir (Filya, 2001; Filya ve ark., 2004; Koç ve ark., 2010). Bunun sonucunda başta maya ve küf 
olmak üzere, silajda bozulmaya neden olan aerobik mikroorganizmalar aktif hale ISSN:1307-3311 geçmektedir. $\mathrm{Bu}$ mikroorganizmalar ortamda bulunan fermantasyon ürünlerini tüketerek büyük miktarlarda besin madde kayıplarına neden olurlar (Ranjit ve Kung, 2000; Kung ve ark., 2003; Filya ve ark., 2004; Koç ve ark., 2010). Söz konusu oluşumun saha koşullarındaki en tipik belirleyicisi, kitle içerisinde sıcaklığın yükselmesi, karbondioksit ve su oluşumu ile maya ve küf gelişimidir (Koç ve ark., 1999; Koç ve ark., 2010). Açım sonrası kitlenin hava ile teması sonucunda gerçekleşen aerobik bozulma ve bu yolla meydana gelen kayıplar, silajın kullanım etkinliğini belirleyen önemli bir unsurdur (Koç ve ark., 1999). Bu şekilde bozulmuş silajlar hayvanlar tarafindan ya az tüketilir ya da hiç tüketilmeyebilir. Ayrıca bu tip silajlarda oluşan küf mantarları, hayvanlar için öldürücü olabilecek mikotoksinleri üretebilirler. Bunlar da hayvansal ürünler ile birlikte insanlara geçerek sağlık açısından risk oluşturabilirler (Te Giffel ve ark., 2002; Koç ve ark., 2010; Liu ve ark., 2013).

\section{Aerobik Stabiliteyi İyileştirme Stratejileri}

Silajlarda aerobik stabilite açısından hedef, silajın açıldığı dönem de dâhil olmak üzere, silaj içerisinde önemli düzeyde bir sıcaklık artışı veya gözle görülebilir nitelikte bir küf oluşmadan, 168 saat (7 gün) havaya maruz kalabilmeyi başarmaktır (Wilkinson ve Davies, 2012). Bu hedefi tutturabilmek için başlıca dört temel strateji mevcuttur. (1) hasat öncesi silolanacak ürünün maya ve küf ile bulaşmasını en aza indirmek, (2) silaj kütlesini yeteri kadar sıkıştırmak, (3) etkin bir örtü malzemesi ile siloyu kapatarak geçirgenliği önlemek ve (4) yemleme için açılan yüzeyi azaltmak, açım sonrası hava girişini engelleyici önlem almaktır. Tüm bunlar için dikkat edilmesi gereken hususlar aşağıda sıralanmıştır:

-Silolanacak materyal en uygun olgunlaşma döneminde hasat edilmeli, kuru madde içeriği \%25-35, SÇK içeriği ise en az \%3 olmalıdır. Su içeriği yüksek olan materyal silolanmadan önce bir miktar soldurulmalıdır. Ancak soldurma süresi iki günü geçmemelidir.

-Vejetasyon gelişimi esnasında gerekli ve yeterli bitki koruma tedbirleri ile silolanacak ürünün hasat öncesi maya ve küf ile bulaşma riski en aza indirilmelidir.

-Silaj materyali bitkinin çeşidine göre uygun büyüklükte parçalanmalı, silo aşırı olmamak kaydıyla hızlı ve homojen bir dağılım olacak şekilde sıkıştırılarak doldurulmalıdır.

-Silajlarda iyi bir fermantasyon oluşturabilmek, bozulmayı engellemek, stabiliteyi iyileştirmek ve besin madde içeriğini arttırabilmek için materyalin özelliğine göre, silaj içerisine katkı maddesi ilave edilebilir. Bu konuda silajlık materyalin kimyasal ve fiziksel özellikleri ile katkı maddesinin fiyatı, uygulanabilirliği ve etki mekanizması dikkate alınarak tercih yapılabilir.

-Silonun doldurulması tamamlanır tamamlanmaz üzeri mümkün olduğu kadar hızlı bir şekilde hava geçirmez ve sızdırmaz polietilen plastik malzeme ile kapatılmalı ve içerideki havayı dışarı atabilmek için üzeri ağır cisimler ile kapatılmalıdır.

-Hayvanlara silaj verilmek üzere silo açıldıktan sonra kalite ve stabilitenin korunabilmesi için her açımda sonra silaj, kontrollü bir şekilde açılmalı ve yine kontrollü bir şekilde kapatılmalıdır. Bu uygulama silajın stabilitesinin korunabilmesi ve kayıpların en aza indirilmesi açısından son derece önem arz etmektedir. Silajın alınması ve rasyonun diğer bileşenleri ile karıştııılmasını sağlayan yem karma vagonlarından yararlanılması, stabilitenin devamlılığını sağlayacağı gibi muhtemel kayıpların azaltılmasında da etkin rol oynayacaktır.

\section{SONUÇ VE ÖNERILER}

Silajlarda gerçekleşen fermantasyonun genel ilkeleri göz önünde bulundurulduğunda, özellikle yemleme döneminde, tüm silajlarda aerobik bozulma kaçınılmaz bir sonuçtur. Fakat bunun en aza indirilmesi için gerekli tedbirlerin alınması, üzerinde hassasiyetle durulması gereken bir konu olarak karşımıza çıkmaktadır. Bunun için silaj yapılacak materyal en uygun zamanda hasat edilmeli, uygun boyutlarda parçalanmalı, iyi bir şekilde sıkıştırılarak hava almayacak şekilde kapatılmalıdır. Bütün önlemler alınmış olmasına rağmen aerobik stabilite açısından telafi edilemeyecek kadar önemli bir risk söz konusu 
olduğunda, stabiliteyi iyileştirmek için uygun katkı maddesi kullanılabilir. Ayrıca aerobik stabilite ile ilgili sorunlar genellikle büyük ölçekli silolarda daha sık karşımıza çıkmaktadır. Son yıllarda silaj yapım teknolojisindeki gelişmelerle birlikte günlük tüketime uygun balya ve paket silaj kullanımı da giderek yaygın hale gelmiş ve dolayısıyla da geleneksel silajlarda sıkça karşılaşılan aerobik stabilite sorunlarının balya veya paket silaj yapımı ile en aza indirgenebileceği söylenebilir.

\section{KAYNAKLAR}

Ashbell, G., Weinberg, Z. G., Hen, Y., Filya, I., 2002. The effects of temperature on the aerobic stability of wheat and corn silages. Journal of Industrial Microbiology and Biotechnology, 28(5), 261-263.

Basmacıŏlu, H., Ergül, M., 2002. Silaj Mikrobiyolojisi. Hayvansal Üretim 43(1): 12-24.

D’Amours, L., Savoie, P., 2005. Density profile of corn silage in bunker silos. Canadian Biosystems Engineering/Le génie des biosystèmes au Canada 47: 2.21-2.28.

Danner, H., Holzer,M., Mayrhuber,E., Braun, R., 2003. Acetic acid increases stability of silage under aerobic conditions. Applied and Environmental Microbiology, 69(1), 562-567.

Driehuis, F., Oude Elferink, S. J. W. H., Van Wikselaar, P. G., 2001. Fermentation characteristics and aerobic stability of grass silage inoculated with Lactobacillus buchneri, with or without homofermentative lactic acid bacteria. Grass and Forage Science, 56(4), 330-343.

Filya, I, Ashbell, G., Hen, Y., Weinberg, Z.G., 2000. The effect of Bacterial inoculants on the fermentation and aerobic stability of whole crop wheat silage. Anim. Feed Sci. Technol. 2000; 88: 39-46.

Filya, İ., 2001. Silaj Fermantasyonu. Atatürk Üniversitesi Ziraat Fakültesi Dergisi, 32 (1), 87-93.

Filya, İ., 2002. Laktik asit bakteri ünokulantlarının mısır ve sorgum silajlarının fermantasyon, aerobik stabilite ve in situ rumen parçalanabilirlik özellikleri üzerine etkileri. Turk J. Vet. Anim Sci. 26: $815-823$.

Filya, İ., Sucu, E., Ö. Canbolat., 2004. Silaj fermantasyonunda organik asit kullanımı üzerinde araştırmalar. 2. Formik asit temeline dayalı bir koruyucunun çiftlik koşullarında yapılan misır silajlarının fermantasyon, mikrobiyal flora, aerobik stabilite ve in situ rumen parçalanabilirlik özellikleri üzerine etkisi. Uludağ Üniv. Zir. Fak. Derg., 18 (2): 35-45.

Johnson, L. M., Harrison, J. H., Davidson, D., Mahanna, W. C., Shinners, K., Linder, D., 2002. Corn silage management: Effects of maturity, inoculation, and mechanical processing on pack density and aerobic stability. Journal of Dairy Science, 85 (2), 434-444.

Kaya, Ö., 2005. Tekirdağ İli koşullarında yetiştirilen birinci ve ikinci ürün mısır çeşitlerinin silaj kalitesi ve aerobik dayanıklılıkları üzerine etkileri. Trakya Üniversitesi Fen Bilimleri Enstitüsü Yüksek Lisans Tezi. https://tez.yok.gov.tr/UlusalTezMerkezi/. U. T: 14.10.2014.

Keleş, G., Yazgan, O., 2011. Fermentation characteristics of maize silages ensiled with lactic acid bacteria and the effect of inoculated baled maize silages on lamb performance. Journal of the Faculty of Veterinary Medicine, University of Kafkas, 17 (2): 229-234, Kars (Turkey).

Koc, F., Coskuntuna, L., Ozduven, L., 2008. The effect of bacteria+ enzyme mixture silage inoculant on the fermentation characteristic, cell wall contents and aerobic stabilities of maize silage. Pakistan Journal of Animal Science, 7(2), 222-226.

Koç, F., Coşkuntuna, L., Özdüven, M. L., Coşkuntuna, A., 2010. Farklı ortam sıcaklıklarında organik asit kullanımının fĭğ-tahıl silajlarında fermantasyon gelişimi ve aerobik stabilite üzerine etkileri (The effect of organic acid usage at various temperatures on fermentation and aerobic stability of vetch-grain silages). JOTAF/Tekirdağ Ziraat Fakültesi Dergisi, 7(2), 159-165.

Koç, F., Özdüven, M. L., Yurtman, İ. Y., 1999. Tuz ve mikrobiyal katkı maddesi ilavesinin mısırsoya karışımı silajlarda kalite ve aerobik dayanıklılık üzerindeki etkileri. Hayvansal Üretim, 40(1), 64-71.

Knicky, M., 2005. Possibilities to Improve Silage Conservation. Effects of Crop, Ensiling Technology and Additives. Swedish University of Agricultural Sciences. Doctoral thesis. http://pub.epsilon.slu.se/834/1/Thesis_for_epsilon2.pdf ; Erişim Tarihi: 15.02.2016.

Kung, L., 2010. Aerobic stability of silage. In Proceedings of California Alfalfa \& Forage Symposium and Corn/Cereal $\quad$ Silage $\quad$ Conference. http://alfalfa.ucdavis.edu/+symposium/2010/files/talks/CAS10_KungAnaerobicStability.pdf Erişim Tarihi: 11.03.2015.

Kung, L., Ranjit, N. K., 2001. The effect of Lactobacillus buchneri and other additives on the fermentation and aerobic stability of barley silage. Journal of Dairy Science, 84(5), 11491155. 
Kung, L., Taylor, C. C., Lynch, M. P., Neylon, J. M., 2003. The effect of treating alfalfa with ISSN:1307-3311 Lactobacillus buchneri 40788 on silage fermentation, aerobic stability, and nutritive value for lactating dairy cows. Journal of Dairy Science, 86(1), 336-343.

Kutlu, H. R., 2015. Tüm yönleriyle silaj yapımı ve silajla besleme. Çukurova Üniversitesi Ziraat Fakültesi Zootekni Bölümü http://www.zootekni.org.tr/upload/File/SILAJ\%20El\%20KTABI.pdf; Erişim Tarihi: 03.04.2015

Liu, Q. H., Shao, T., Zhang, J. G., 2013. Determination of aerobic deterioration of corn stalk silage caused by aerobic bacteria. Animal Feed Science and Technology, 183(3), 124-131.

Mohd-Setapar, S. H., Abd-Talib, N., Aziz, R., 2012. Review on crucial parameters of silage quality. APCBEE Procedia, 3, 99-103.

Muck, R. E., 2004. Effects of corn silage inoculants on aerobic stability.Transactions-American Society Of Agricultural Engineers,47(4), $1011-1016$. http://fyi.uwex.edu/forage/files/2014/01/Muck-Inoc.pdf ; Erişim Tarihi: 06.05.2015.

Muck, R. E., Holmes, B. J., 2000. Factors affecting bunker silo densities. Applied Engineering in Agriculture, 16(6), 613-620.

Muck, R. E., Shinners, K. J., 2001. Conserved forage (silage and hay): progress and priorities. In International Grassland Congress (Vol. 19, pp. 753-762). São Pedro: SBZ. http://www.internationalgrasslands.org/files/igc/publications/2001/tema21-1.pdf ; Erişim Tarihi: 06.05.2015.

Polat, C., Koç, F., Özdüven, M. L., 2005. Mısır silajında laktik asit bakteri ve laktik asit bakteri+ enzim karışımı inokülantların fermantasyon ve toklularda ham besin maddelerinin sindirilme dereceleri üzerine etkileri. JOTAF/Tekirdağ Ziraat Fakültesi Dergisi, 2(1), 13-22.

Ranjit, N. K., Kung, L., 2000. The effect of Lactobacillus buchneri, Lactobacillus plantarum, or a chemical preservative on the fermentation and aerobic stability of corn silage. Journal of Dairy Science, 83(3), 526-535.

Sucu, E., Filya, I., 2006. The effects of bacterial inoculants on the fermentation, aerobic stability and rumen degradability characteristics of wheat silages. Turkish Journal of Veterinary and Animal Sciences, 30(2), 187-193.

Te Giffel, M. T., Wagendorp, A., Herrewegh, A., Driehuis, F., 2002. Bacterial spores in silage and raw milk. Antonie van Leeuwenhoek, 81(1-4), 625-630.

Toruk, F., Koç, F., Gönülol, E., 2010. Aerobik stabilite süresince paket silajlarında renk değişimi. Tekirdağ Ziraat Fakültesi Dergisi, 7(1).

Wilkinson, J. M., Davies, D. R., 2012. Targets for the aerobic stability of silage. XVI. International Silage Conference, 67. Hämeenlinna, Finland, 2-4 July 2012.

Wilkinson, J. M., Davies, D. R., 2013. The aerobic stability of silage: key findings and recent developments. Grass and Forage Science, 68, 1-19 